\title{
Sign Language as Accommodation for Deaf Students in Accessing Education at Universities
}

\author{
Dwi Setianingsih \\ Special Education Department, Faculty of Teacher Training and Education \\ University of PGRI Yogyakarta \\ dwisetianingsih@upy.ac.id
}

\begin{abstract}
Education is the right of every Indonesian citizen, including persons with disabilities. Inclusive education as a form of education for all has not been well implemented at the university level. Deaf children who are studying at a university have not received proper accommodation. The purpose of this study was to identify the barriers of deaf in accessing education and the right solutions to overcome these problems. Based on literature studies, observations, and interviews with the deaf, obtained results that (1) Deaf children have obstacles to hearing, so vocabulary mastery and language development are hampered. Cognitive development is one of the important abilities that every child must have, and language authority is very influential. Whereas for the deaf children, language mastery is hampered due to hearing barriers that children with hearing impairment have. While the language acquisition of deaf children is obtained from sign language, which in practice has not received support from the environment. At the tertiary level the needs of deaf children remain the same, namely access to sign language as their mother language; (2) deaf children are individuals who have their own uniqueness, in the form of a conditional culture. Sign language has its own language structure as other languages such as syntax, morphology, semantics and phonology. So that in providing accommodation for deaf children both in the scope of basic education to higher education, in the form of the use of sign language to be able to access education.
\end{abstract}

Keywords — deaf student, accommodation, sign language.

\section{INTRODUCTION}

Indonesia's long history of fighting for the right to obtain education began with the practice of "reciprocity" by the Dutch East Indies government, even now education is still the thing that must be fought for by those who still get discrimination due to circumstances [1]. In terms of legislation, as a country, Indonesia has the 1945 Constitution as a reference for the implementation of education with one article, namely Article 31 which reads "that every citizen has the right to education". Then Law No. 20 of 2003 concerning the National Education System also strengthens the position of education for all with Article 5 which states that "every citizen has the same right to obtain education". In line with that in Law No. 8 of 2016 which also became the affirmation of Law No.4 of 1997 concerning Disabled Persons mentioned the same thing. More clearly mentioned in Article 10 of Law No. 8 of 2016 concerning Persons with Disabilities that: Educational Rights for Persons with Disabilities include rights: a) get quality education in education units in all types, paths and levels of education in an inclusive and special manner, b) have equal opportunities to become educators or educators in education units in education units in all types, paths and levels of education, c) have equal opportunities as qualified education providers; there are education units in all types, paths, and educational levels; and d) get Eligible Accommodation as students.

Based on the regulation, every child has the right to get education starting from the elementary level to the college level. The Government of Indonesia strives to provide education so that it can run democratically and justly and not discriminatively by upholding human rights, religious values, cultural values and national diversity. Within this framework, the government organizes education by paying attention to the differences found in individuals. Judging from the context, citizens are normal (no having diffability) given access to education, so also with abnormal citizens (persons with disabilities) given similar access. This is evidenced by the existence of courses or schools have special training called the Special School (SLB).Like schools in general, SLB in Indonesia has a level or from elementary school (SD) to high school (SMA). While for special education institutions for universities still do not exist in Indonesia. Based on this, this study aims to identify the impact of deaf barriers in accessing education and the right solutions to overcome these problems.

\section{METHOD}

The research design used in this study is a qualitative approach. Researchers use a qualitative approach because this research is a field study to describe and analyze phenomena, events, activities of a group in this case is the use of sign language as accommodation for deaf children in accessing tertiary education.

In line with the objectives and formulation of research problems, this study uses a qualitative approach using qualitative descriptive research methods with case study designs. The steps taken in data analysis are through data reduction, data presentation or data display and conclusion drawing (conclusions) and verification [2], with research participants being deaf teenagers, sign language observers, sign language and energy researchers educator for deaf children. 
Data collection techniques using observation, interviews, documentation. Test the validity of the data by extension of observation and triangulation. Data processing and analysis techniques use data reduction, data presentation, and data verification.

\section{RESULT AND DISCUSSION}

\section{A. Accessibility For Deaf's Students}

No exception, children with hearing impairment, they also have the right to get education together with children in general. Deafness is an inability to hear accompanied by an inability to communicate normally. Deafness can be interpreted as a loss of the ability of hearing power in part or in whole, which results in the development of speech and language skills are hampered [3].

From this definition it can be concluded that children with hearing impairment are those who experience obstacles in hearing function so that they have an impact on the inability to hear and communicate verbally. Deaf itself is an identity that has its own uniqueness, including culture and how to communicate with one another. Cues become the scientific language and identity of deafness, so the use of sign language for deaf children is very important in all aspects of life.

According to a report from WFD (World Federation for the Deaf) there are 70 million deaf communities worldwide, of which $0.5 \%$ of those aged 10-17 years actually have low literacy compared to children who hear normal 9-10 years of age. This also happens in Indonesia, on average deaf children to deaf adults have low literacy skills carried on average by children who hear normal 9-10 years of age. Those who graduated from SLB B and graduated from general high school, and a small percentage who had time to demand higher education at the University also experienced difficulties in understanding reading and writing in Indonesian. the low literacy ability of deaf children is due to the inappropriate use of language as a bridge in the development of cognition. This sign culture that becomes deaf identity is not well facilitated, so that the cognitive abilities of deaf children cannot develop optimally.

According to [4] arousal raises a core impact on language development. Barriers to developing one's own language give rise to complex impacts such as in terms of education, socialemotional, intelligence and personality aspects. The impact of the hearing loss results in cognitive development, namely on academic achievement, or learning achievement. In the process of learning and cognitive development, it is important that children get examples that are appropriate to themselves, so that they are able to position themselves how they should behave in the general public.

Language development of deaf children becomes an important part and becomes the key to the beginning of other development openings. According to [5] that parents who are more accepting of their children and are more active in training their children are flexible parents and perseverance in finding ways to communicate effectively. Furthermore according to Drasgrow, 1998; Hart, and Risley 1995 in [5] that the quality of communication between parents and children is likely to be one of the best predictions of language development, and this is a clarity of the main factors in academic success.

In order to accommodate deaf disability, sign language is something that needs to be cultivated especially at the university level. In line with that effective communication is using bilingual sign language where natural sign language (BISINDO) is the first language and Indonesian as the second language in writing [6]. For example, in learning English, the implementation will use bilingual, namely Indonesian as a national language, and English as the language studied. This is reinforced by the findings [7] with 100 deaf and teenage adults (16-50 years) in various regions, as evidenced by the fact that a majority of deaf $91 \%$ have used BISINDO in communication between humans, while SIBI has only $9 \%$ who have used it.

\section{B. Sign Language}

Sign language as a language that has its own linguistic and linguistic structure has been proven by many researchers around the world and recognized by the National Examination, one of which is according to (Vygotsky, 1996a, p. 91) in [8], that sign language is language which is complex with its own syntax, a language that develops very richly. Added by (Markku Jokinen, 2005) in the writings of [8], sign language is a language that uses hands to provide many meanings, which can be understood visually. Sign language such as other conversation languages, which have phonology, morphology, syntax, semantics and language rules themselves to be referred to as "language". Sign language is also a visual-gestural language, while conversation language is auditory-vocal language.

\section{Inclusion Education In University}

Following up on this, the university must be prepared to accept and the most important thing is to accommodate prospective students with special needs. Of course prospective students who have cognitive abilities that support education at the university level. As a manifestation of the implementation of Law No. 8 of 2016 concerning Persons with Disabilities, that Universities must be prepared to become providers of inclusive education. This is what many universities have not done.

Some universities in Indonesia have become the organizers of inclusive education, some of which are Sunan Kalijaga University, Brawijaya University with the existence of a service center for disability studies. Other universities actually have indirectly implemented this inclusive education policy, namely by accepting students with special needs, with various types of disabilities. However, the implementation is still not optimal in providing accommodation that suits the needs of students with disabilities. some of the things that become obstacles are lack of knowledge about persons with disabilities, as well as the fulfillment of their needs. So that people with disabilities must try harder to be able to adjust themselves to attending education.

Appreciate the concern of universities that organize inclusive education, Ministry of Education and Culture 
(KemenDikBud) cooperating with Helen Keller InternationalIndonesia to provide Inclusive Awards. Inclusive awards are awards given to parties who are considered to have been instrumental in realizing the implementation of education inclusive or education of children with special needs in Indonesia. There is some universities that have received this award, including UB and UIN SUKA in 2013 [9].

Thus, the use of sign language at the university level is expected to help deaf children's cognitive development in order to develop optimally. Language proficiency, and cognitive development are formed from experiences that show children the relationship between their concepts and labels. They can build a simple conceptual system of a part because the language and behavior of adult, or older deaf people have separated the world in various ways, which make cognitive, social, and cultural understanding [5].

This is in line with Law number 8 of 2016, namely the Disability Act explaining sign language is a form of nonphysical accessibility services. Sign Language used officially in law is a natural sign language from the deaf community.

\section{CONCLUSION}

Inclusion education is one manifestation of the education movement for all, so that universities must also prepare themselves to become providers of inclusive education. Children with hearing impairments have an impact on hearing ability, and further make their cognitive abilities also experience obstacles. This is because the deaf child himself is actually not just losing his hearing function, but is a unique individual, namely with a sign culture which is the natural language of birth.

The impact of hearing impairment on deaf students is that children are unable to access the external environment through hearing. In the field of education too, deaf students experience obstacles in accessing lessons in school. So that cognitive development also experiences obstacles, if you don't get accommodation that suits your needs. As a deaf, acquiring language not through verbal, will remain through non verbal or sign language. In accommodating deaf children at high levels in accessing education, the use of sign language is very important. Because as a manifestation of the fulfillment of the disability rights of the deaf in Law No. 8 of 2016 concerning persons with disabilities.

\section{REFERENCES}

[1] M. Buchori, Evolusi Pendidikan di Indonesia. Yogyakarta: Insist Press, 2007.

[2] J. . Creswell, Educational Research - Planning, Conducting, And Evaluating Quantitative And Qualitative Research. Third Edition. New Jersey: Pearson Education, Inc, 2008.

[3] A. Marsudiharjo, Didaktik Metodik Umum Pemerolehan Kemampuan Berbahsa Anak Tunarungu. Jakarta: Putra Perkasa, 2013.

[4] E. Sadjaah, Pendidikan Bahasa Bagi Anak dengan Gangguan Pendengaran dalam Keluarga. Jakarta: Departemen Pendidikan Nasional, 2005.

[5] M. Marschark, H. G. Lang, and J. A. Albertini, Educating Deaf Studies. New York: Oxford University Press, 2002.

[6] I. H. Zusfindhana, "Penggunaan Bahasa Isyarat Sibi Dan Bisindo Oleh Siswa Tunarungu Remaja Di Slb-B Kota Bandung," Magister Tesis Magister Program Pascasarjana Universitas Pendidikan Indonesia, 2015.

[7] R. A. Mursita, "Respon Tunarungu terhadap Penggunaan Sistem Bahasa Isyarat Indonesa (SIBI) dan Bahasa Isyarat Indonesia (Bisindo) dalam Komunikasi," J. Inklusi, vol. 2, no. 2, 2015.

[8] G. S. Soejanto, "Galuh Sukmara (Master of Sign Linguistics-La Trobe University, Melbourn)," The Journey into The Deaf World in Indonesia. Not Published., 2010.

[9] R. Abdi, "Implementasi Kebijakan Pendidian Inklusif di Pergurauan Tinggi Negeri Indonesia (Studi Komparasi Universitas Islam Negri Sunan Kalijaga,Universitas Brawijaya Dan Universitas Gadjah Mada)," Tesis Magister Fakultas Ilmu Sosial dan Politik Universitas Gajah Mada, 2015 . 